DOI https://doi.org/10.30525/978-9934-26-026-1-8

\title{
DISPROPORTIONS IN ECONOMIC DEVELOPMENT OF THE COUNTRIES WITHIN THE LEADING INTEGRATION ENTITIES OF THE WORLD
}

\section{Palinchak M. M., Brenzovych K. S., Mashkara-Choknadiy V. V.}

\section{INTRODUCTION}

The expansion and deepening of integration processes that affect the qualitative and quantitative features of the development of all forms of international economic relations are important features of the modern world economy. Strengthening the economic interdependence of national economies at bilateral, subregional, regional and interregional levels has become a requirement in modern international economic relations. Specific forms of economic interaction depend on the economic development of the participating countries, and their characteristics accordingly influence the nature and driving forces of integration. On the other hand, the participation of countries in integration associations affects various aspects of their economies, that maces this topic of research urgent and important.

Several major integration entities have emerged in macro-regions of the world, which have gained considerable weight in the world's socio-political and economic processes. Such integrations are being at different stages of integration, and in addition to economic functions (promoting mutual trade and economic cooperation in general), they aslo serve to the pursuit of common political interests and to enhancing the role of the countries of the region in the world economy and politics. The purpose of this study is to evaluate the level of economic development of the countries of the three leading regional integration entities of the world, formed and operating in different parts of the world - the European Union, NAFTA and ASEAN, to compare the main macroeconomic indicators during participation in integration processes, to determine the positive and negative influences of integration on the economic development of the member states.

\section{Dynamics of economic development of the European Union members}

The European Union holds a special place among the most important economic entities of the world showing the deepest level of integration of economic systems and the longest time experience of successful cooperation (more than 50 years). 
Since the founding of the European Union, countries that initiated the formation of this integration union have created the economic and political core of the union. Belgium, the Netherlands, France, Germany, Italy and Luxembourg, together with the later accessed United Kingdom and the Scandinavian countries (Denmark and Sweden) have formed indisputable leadership among other members of the union ${ }^{1}$.

Four of the ten leading economies in the world in terms of GDP Germany, Great Britain, France, Italy, whose total contribution to world GDP is $13.6 \%$ are the EU members ${ }^{2}$. The EU as a whole accounts for $22 \%$ of the world GDP. At the same time, the grouping includes countries that are significantly different from the leaders in terms of their economic performance and structure.

The following general macroeconomic indicators of EU member states characterize their economic development: GDP and GDP per capita, income levels, inflation rate, public debt percentage to GDP. In the EU's total gross product, the leading place belongs to the leaders - Germany, the United Kingdom, France, Italy and Spain, which account for more than $70 \%$ of total GDP of the union ${ }^{3}$. However, these same leading countries show relatively moderate economic growth rates, while countries that joined the EU after 2004 have higher GDP growth rates than the EU average as it is shown at the Table 1.

The major part of the EU's external debt $(70 \%)$ is made up by the economies of the leading countries - Germany, France, the United Kingdom and Italy, and for these economies the external debt-to-GDP ratio is rather high (higher than the EU average). On the contrary, the most countries, who joined after 2004 have a moderate level of debt (from $8 \%$ for Estonia to $70 \%$ for Hungary). Portugal, Spain and Cyprus have a high debt-to-GDP ratio, and Greece is having the largest indicator for a long time. According to the World Economic forum, Greece is the second country in the list of the countries with the highest dept - to GDP ratio (181\%) after Japan, which dept exceeds GDP 2,3 times ${ }^{4}$.

${ }^{1}$ Носа А.М. Економічна нерівність у країнах Європейського Союзу та її вплив на місце СС у світовому економічному середовищі. Науковий вісник УжНУ. Серія «Міжнародні економічні відносини та світове господарство». 2017. Вип. 13. Ч. 2. C. 51-55. URL: http://www.visnyk-econom.uzhnu.uz.ua/archive/13_2_2017ua/13.pdf

2 The World's \$86 Trillion Economy Visualized in One Chart. URL: https://howmuch.net/articles/the-world-economy-2018.

${ }^{3}$ US vs EU - A GDP Comparison. URL: https://mgmresearch.com/us-vs-eu-a-gdpcomparison/

4 These EU countries have the most government debt. URL: https://www. weforum.org/agenda/2019/05/european-countries-with-most-government-debt-chart/ 
Table 1

Main macroeconomic indicators of the EU countries $5,6,7,8$

\begin{tabular}{|l|c|c|c|c|c|c|}
\hline \multicolumn{1}{|c|}{ Country } & $\begin{array}{c}\text { GDP } \\
\text { USD } \\
\text { billion } \\
\mathbf{( 2 0 1 8 )}\end{array}$ & $\begin{array}{c}\text { Share in the } \\
\text { total GDP of } \\
\text { the EU, \% } \\
(\mathbf{2 0 1 8 )}\end{array}$ & $\begin{array}{c}\text { GDP } \\
\text { growth } \\
\mathbf{2 0 1 8} \text { to } \\
\mathbf{2 0 1 7 ,} \%)\end{array}$ & $\begin{array}{c}\text { Public dept, } \\
\text { US billion } \\
\text { (1st quarter } \\
\text { of 2019) }\end{array}$ & $\begin{array}{c}\text { Public debt, } \\
\text { \% GDP, } \\
\text { (1st quarter } \\
\text { of 2019) }\end{array}$ & $\begin{array}{c}\text { Inflation } \\
\text { rate, \% } \\
\text { (June 2019) }\end{array}$ \\
\hline Germany & 4029 & $\mathbf{2 1 , 3}$ & 1,9 & 2077,66 & 61 & 1,5 \\
\hline G. Britain & 2809 & 15,2 & 1,4 & 2121,94 & 85,3 & 2,0 \\
\hline France & 2795 & 14,9 & 1,6 & 2358,90 & 99,7 & 1,4 \\
\hline Italy & 2087 & 11,2 & $\mathbf{1 , 2}$ & 2358,54 & 134 & 0,8 \\
\hline Spain & 1437 & 7,6 & 2,7 & 1200,26 & 98,7 & 0,6 \\
\hline Netherlands & 910 & 4,8 & 2,8 & 398,04 & 50,9 & 2,7 \\
\hline Sweden & 555 & 3,1 & 2.4 & 169,25 & 36,3 & 1,6 \\
\hline Poland & 549 & 3,0 & 4,4 & 245,29 & 49,1 & 2,3 \\
\hline Belgium & 536 & 2,9 & 1,5 & 477,13 & 105,1 & 1,3 \\
\hline Austria & 459 & 2,4 & 2,8 & 282,62 & 72,7 & 1,6 \\
\hline Ireland & 366 & 1,9 & 4,7 & 215,48 & 65,6 & 1.1 \\
\hline Denmark & 355 & 1,9 & 2,0 & 101,06 & 33,6 & 0,5 \\
\hline Finland & 277 & 1,5 & 2,6 & 138,79 & 59,3 & 1,1 \\
\hline Czechia & 245 & 1,3 & 3,1 & 71,14 & 34 & 2,4 \\
\hline Portugal & 239 & 1,3 & 4,0 & 250,36 & 123 & 0,7 \\
\hline Romania & 238 & 1,2 & 2,3 & 69,19 & 34,1 & 3,9 \\
\hline Greece & 218 & 1,2 & 2,0 & 337,41 & 181,5 & 0,2 \\
\hline Hungary & 156 & 0,8 & 4,0 & 93,91 & 70,1 & 3,4 \\
\hline Slovakia & 107 & 0,6 & 3,9 & 44,8 & 48,9 & 2,7 \\
\hline Luxemburg & 69 & 0,4 & 4,0 & 12,63 & 21,3 & 1,5 \\
\hline Bulgaria & 64 & 0,3 & 3,6 & 12,01 & 21,2 & 2,3 \\
\hline Croatia & 60 & 0,3 & 2,8 & 38,72 & 74,5 & 0,5 \\
\hline Slovenia & 55 & 0,3 & 4,5 & 31,58 & 67,9 & 1,9 \\
\hline Lithuania & 52 & 0.3 & 3,5 & 15,63 & 34,1 & 2,4 \\
\hline Latvia & 34 & 0,2 & 3,7 & 11,15 & 37,2 & 3,1 \\
\hline Estonia & 30 & 0,2 & 3,7 & 2,11 & 8,1 & 2,6 \\
\hline Cyprus & 24 & 0,1 & 4,0 & 22,0 & 105 & 0,3 \\
\hline Malta & 14 & 0,1 & 5,7 & 5,85 & 46,6 & 1,8 \\
\hline Total, EU & $\mathbf{1 8 7 6 9}$ & $\mathbf{1 0 0}$ & $\mathbf{2 , 2}$ & $\mathbf{1 3 1 6 3 , 4 5}$ & $\mathbf{8 5 , 9}$ & $\mathbf{1 , 6}$ \\
\hline & & & & & & \\
\hline
\end{tabular}

${ }^{5}$ National debt in EU countries in the 1st quarter 2019 in relation to gross domestic product. URL: https://www.statista.com/statistics/269684/national-debt-in-eu-countriesin-relation-to-gross-domestic-product-gdp/

${ }^{6}$ National debt in the member states of the European Union in the 1st quarter 2019 (in billion euros). URL: https://www.statista.com/statistics/274179/national-debt-in-eu-countries/

${ }^{7}$ Inflation rate in EU countries in June 2019 (compared to the same month of the previous year). URL: https://www.statista.com/statistics/225698/monthly-inflation-rate-ineu-countries/

${ }^{8}$ Gross domestic product (GDP) at current market prices of selected European countries in 2018 (in billion euros). URL: https://www.statista.com/statistics/685925/gdpof-european-countries/ 
As for the price level, the inflation rate as of July 2019 did not differ significantly between EU countries and ranged from a minimum of $0.3 \%$ in Cyprus to $2.7 \%$ in Slovakia and the Netherlands, indicating the effectiveness of currency regulation in the union.

Luxembourg has the highest GDP per capita among EU member states (98640 Euro), followed by Sweden (70120 Euro) - Figure 1, the lowest indicator was for Latvia, Hungary, Poland, Croatia, Romania. The gap between the highest and the lowest GDP is over $900 \%$. Income inequality is one of the elements of global economic inequality, so while analyzing economic inequality in the EU it is advisable to consider and analyze the incomes of its member states. The minimum wage in the country affects not only the well-being of the population but also the country's labor productivity, as well as the socioeconomic position of the country in international relations. In particular, the average wage level in the European Union is 1,644 Euro. The highest average wages are fixed in Luxembourg (3,500 Euro per month), Denmark (3,350 Euro), Ireland (2,750 Euro), the lowest - in Hungary (675 Euro), Romania (575 Euro), Bulgaria (475 Euro). Thus, Bulgaria's wages are 7.4 times lower than the wages in Luxembourg. However, experts note the narrowing of this gap - for example in 2014, the difference between the maximum and minimum values was more than 9.5 times. In addition, the EU countries that have joined since 2004 are still experiencing a marked level of shadowing of the economy, resulting in that much of their income remains undeclared.

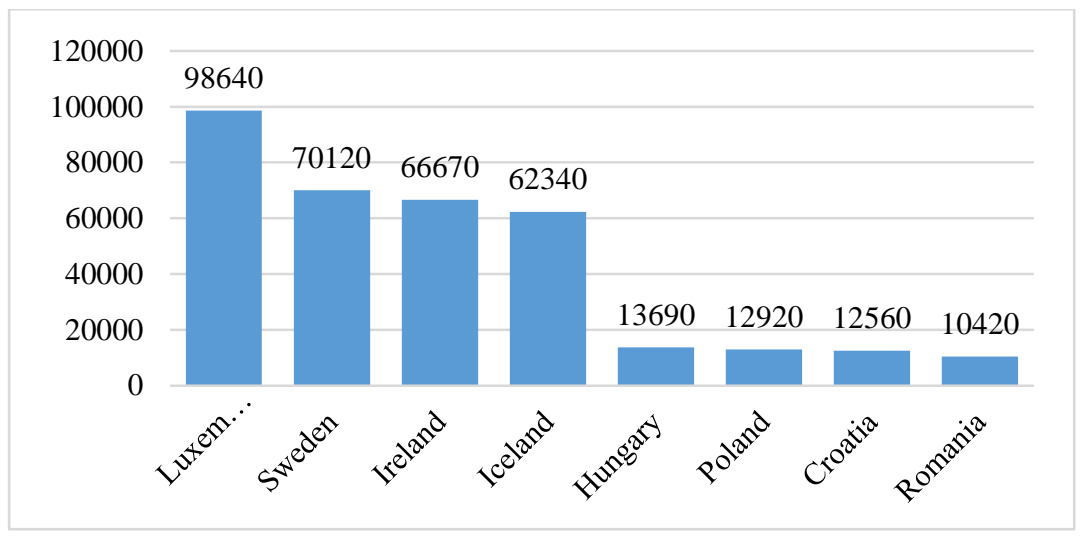

Fig. 1 Countries of the European Union with the highest and lowest GDP per capita in 2018, Euro'

${ }^{9}$ GDP per capita (current US\$) - Poland, Greece, Portugal, Germany, European Union. URL: https://data.worldbank.org/indicator/ NY.GDP.PCAP.CD?locations=PLGR-PT-DE-EU\&name_desc=true 
The differentiation in the levels of economic development of countries, in particular the well-being of citizens, can be estimated using the poverty indicator, the proportion of the population whose incomes are below the minimum required for subsistence. As can be seen from Figure 1, the largest proportion of the poor are in the Baltic States and Southern Europe, the smallest in the Czech Republic, Denmark and Finland. Interestingly, Hungary, Slovakia and Slovenia are among the ten countries with the lowest poverty rates.

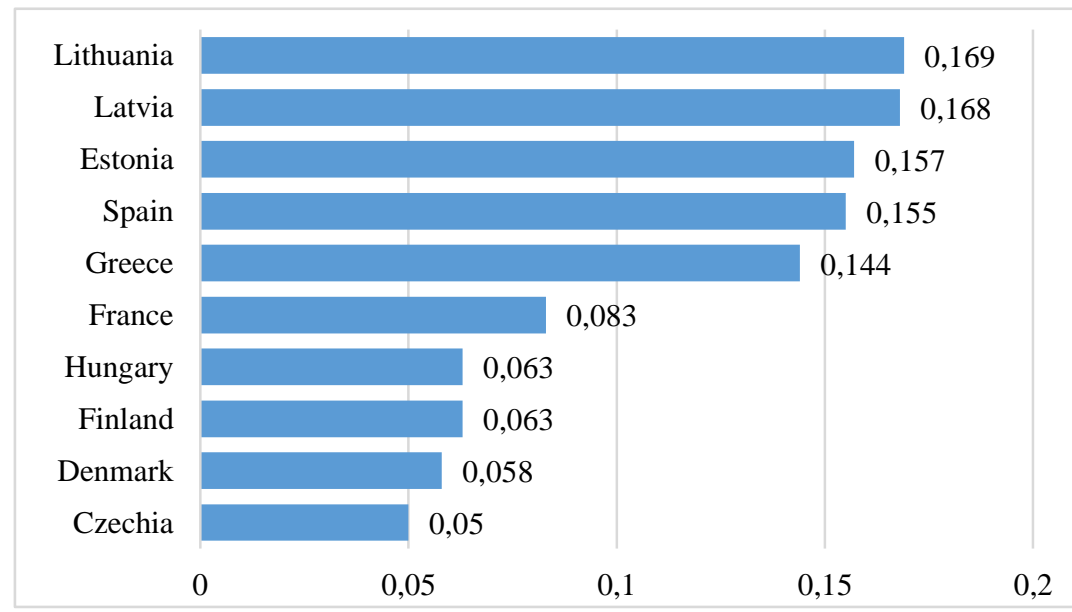

\section{Figure 2 The EU economies with highest and lowest poverty rates in $2018, \%^{10}$}

In terms of employment, the lowest unemployment rates among EU member states in 2019 were recorded in the Czech Republic (2.2\%), Germany $(3.1 \%)$ and Poland $(3.2 \%)$. The highest unemployment rates were observed in Greece (16.7\%) and Spain (14.2\%). Unemployment in 2019 year has declined compared to 2018 in 24 member states and increased only in the Czech Republic (from $2.1 \%$ to $2.2 \%$ ), Lithuania (from $6.1 \%$ to $6.4 \%$ ), Denmark (from $4.9 \%$ to $5.3 \%$ ) and Sweden (from $6.4 \%$ to $6.8 \%)^{11}$.

As we can see, indicators of economic development of the EU member states are quite different, but the most important thing in this study is to

${ }^{10}$ Poverty Rate (OECD Data). URL: https://data.oecd.org/inequality/poverty-rate.htm

11 Euro area unemployment at $7.5 \%$ EU28 at $6.3 \%$. URL: https://ec.europa.eu/ eurostat/documents/2995521/10075437/3-29112019-BP-EN.PDF/749d647b-6961-5d3da8c6-8eaca44a539d 
analyze their dynamics and existing tendencies in closing or braoding the gaps between the most and least developed countrieswith this in mind, we analyze the change in the two most common indicators of developmen the Human Development Index and the Global Competitiveness Index of the countries. The first measures the levels of life, literacy, education and longevity, as the main characteristics of the human potential of the study area, while the second serves to characterize the quality and efficiency of market institutions, the development of entrepreneurial potential, innovation and technological development.

The Table 2 shows the change of Human development index for the EU countries between 2013 and 2018. In 2013, two EU countries - Romania and Bulgaria - belonged to countries with high levels of human development, while the rest were considered as countries with a very high levels of human development. The gap between the highest index value (Denmark, 0.923 or 4th place) and the smallest (Bulgaria, 0.782 or 59th place) in 2013 year was 55 positions. In 2018, EU countries ranked highest (4th place, Ireland) to the lowest (52nd place, Romania) with a gap of 48 positions. All EU countries in 2018, according to the $\mathrm{UN}$, belonged to countries with very high levels of human development, including Romania and Bulgaria.

Table 2

Human Development Index of the EU member states, 2018 and $2013^{12,13}$

\begin{tabular}{|l|c|c|c|c|}
\hline \multicolumn{1}{|c|}{ Country } & HDI (2018)* & Rank (2018) & HDI (2013) ** & Rank (2013) \\
\hline \multicolumn{1}{|c|}{1} & 2 & 3 & 4 & 5 \\
\hline Netherlands & 0,931 & 10 & 0,922 & 5 \\
\hline Germany & 0,936 & 5 & 0,916 & 6 \\
\hline Sweden & 0,933 & 7 & 0,907 & 14 \\
\hline Great Britain & 0,922 & 14 & 0,907 & 14 \\
\hline Denmark & 0,929 & 11 & 0,923 & 4 \\
\hline Finland & 0,920 & 15 & 0,833 & 24 \\
\hline France & 0,901 & 24 & 0,888 & 22 \\
\hline Luxemburg & 0,904 & 21 & 0,892 & 19 \\
\hline Austria & 0,902 & 20 & 0,885 & 23 \\
\hline Belgium & 0,916 & 17 & 0,890 & 21 \\
\hline Spain & 0,891 & 26 & 0,876 & 26 \\
\hline Ireland & 0,938 & 4 & 0,916 & 6 \\
\hline Italy & 0,880 & 28 & 0,873 & 27 \\
\hline Estonia & 0,871 & 30 & 0,861 & 30 \\
\hline Czechia & 0,888 & 27 & 0,870 & 28 \\
\hline Portugal & 0,847 & 41 & 0,830 & 43 \\
\hline Slovenia & 0,896 & 25 & 0,880 & 25 \\
\hline
\end{tabular}

12 Human Development Report 2014. URL: http://hdr.undp.org/sites/default/files/ hdr14-report-en-1.pdf

${ }^{13}$ Human development index 2019. URL: http://hdr.undp.org/en/composite/HDI 
Table 2 (ending)

\begin{tabular}{|l|c|c|c|c|}
\hline \multicolumn{1}{|c|}{1} & 2 & 3 & 4 & 5 \\
\hline Poland & 0,865 & 33 & 0,843 & 36 \\
\hline Malta & 0,878 & 29 & 0,839 & 37 \\
\hline Lithuania & 0,858 & 35 & 0,839 & 37 \\
\hline Latvia & 0,847 & 41 & 0,819 & 46 \\
\hline Slovakia & 0,855 & 38 & 0,844 & 35 \\
\hline Cyprus & 0,869 & 32 & 0,850 & 32 \\
\hline Hungary & 0,838 & 45 & 0,828 & 44 \\
\hline Bulgaria & 0,813 & 51 & 0,782 & 59 \\
\hline Romania & 0,811 & 52 & 0,793 & 52 \\
\hline Greece & 0,870 & 31 & 0,865 & 29 \\
\hline Croatia & 0.831 & 46 & 0,818 & 47 \\
\hline
\end{tabular}

As the table 3 shows, in 2013 EU countries ranked 4 (Finland) to 81 (Greece) among all countries according to the GCI meaning. Changes in the ranking 5 years later indicate a clear trend of improvement in the economic environment of countries. Thus, the gap between the best indicator (Netherlands, 4th place) and the lowest (Croatia, 77th place) narrowed to four positions. Almost all countries that joined the EU after 2004 have improved their positions in the GC ranking.

Table 3

Global Competitiveness Index of the EU countries, 2014 and $2019^{14,15}$

\begin{tabular}{|l|c|c|c|c|}
\hline \multicolumn{1}{|c|}{ Country } & GCI (2019)* & Rank (2019) & GCI (2014)** & Rank (2014) \\
\hline \multicolumn{1}{|c|}{1} & 2 & 3 & 4 & 5 \\
\hline Netherlands & 82,4 & 4 & 5,45 & 8 \\
\hline Germany & 81,8 & 7 & 5,49 & 5 \\
\hline Sweden & 81,2 & 8 & 5,41 & 10 \\
\hline Great Britain & 81,2 & 9 & 5,41 & 9 \\
\hline Denmark & 81,2 & 10 & 5,49 & 13 \\
\hline Finland & 80,2 & 11 & 5,50 & 4 \\
\hline France & 78,8 & 15 & 5,08 & 23 \\
\hline Luxemburg & 77,0 & 18 & 5,17 & 19 \\
\hline Austria & 76,6 & 21 & 5,16 & 21 \\
\hline Belgium & 76,4 & 22 & 5,18 & 18 \\
\hline Spain & 75,3 & 23 & 4,55 & 35 \\
\hline Ireland & 75,1 & 24 & 4,98 & 25 \\
\hline Italy & 71,5 & 30 & 4,42 & 49 \\
\hline Estonia & 70,9 & 31 & 4,71 & 29 \\
\hline
\end{tabular}

14 The Global Competitiveness report 2019. URL: http://www3.weforum.org/docs/ WEF_TheGlobalCompetitivenessReport2019.pdf

${ }^{15}$ The Global Competitiveness report 2014. URL: http://www3.weforum.org/docs/ WEF_GlobalCompetitivenessReport_2014-15.pdf 
Table 3 (ending)

\begin{tabular}{|l|c|c|c|c|}
\hline \multicolumn{1}{|c|}{1} & 2 & 3 & 4 & 5 \\
\hline Czechia & 70,9 & 32 & 4,53 & 37 \\
\hline Portugal & 70,4 & 34 & 4,54 & 36 \\
\hline Slovenia & 70,2 & 35 & 4,22 & 70 \\
\hline Poland & 68,9 & 37 & 4,48 & 43 \\
\hline Malta & 68,5 & 38 & 4,45 & 47 \\
\hline Lithuania & 68,4 & 39 & 4,51 & 41 \\
\hline Latvia & 67,0 & 41 & 4,50 & 42 \\
\hline Slovakia & 66,8 & 42 & 4,15 & 75 \\
\hline Cyprus & 66,4 & 44 & 4,31 & 58 \\
\hline Hungary & 65,1 & 47 & 4,28 & 60 \\
\hline Bulgaria & 64,9 & 49 & 4,37 & 54 \\
\hline Romania & 64,4 & 51 & 4,30 & 59 \\
\hline Greece & 62,6 & 59 & 4,04 & 81 \\
\hline Croatia & 61,9 & 63 & 4,13 & 77 \\
\hline
\end{tabular}

*Scale from 0 to $100 ; * *$ Scale from 0 to 7

Thus, comprehensive indicators also point to the gradual elimination of uneven economic development in EU countries.

\section{Economic development of NAFTA (NAFTA 2.0) members}

The North American Free Trade Area (NAFTA) which is currentry being transformed into United States-Mexico-Canada Agreement is one of the most powerful trading blocs in the world. This union was formed around the United States as one of the world leaders in economic development, which accounts for more than $10 \%$ of world GDP. Along with the United States, NAFTA united Canada's highly developed econome and economy of Mexico, which barely reached the levels of new industrialized nations.

The creation of the Free Trade Area and the further liberalization of economic relations were expected to create a new economic impetus for all NAFTA members and create conditions for a qualitatively new level of economic relations. Currently, all NAFTA Member States are in the top 20 in terms of GDP and exports. The NAFTA economy, which accounts for $6 \%$ of the globe's population, generates over 24 trillion gross product (almost a third of world GDP) and exports $13.2 \%$ of world goods and services - Table 4 .

NAFTA is a phenomenal union of two countries with an innovative model of economic development (the US and Canada) with Mexico - an industrially agrarian country, with the "catching up" development model of development ${ }^{16}$.

16 Кузнецкая О.Д., Шапкина И.Н. История экономики. Москва : ИНФРА-М, 2002. 384 c. 
The specificity of NAFTA is explained by a number of characteristics that differentiate it from both European and other models of international economic integration. The North American Free Trade Area is continental in scope. The following features of integration processes in NAFTA in comparison with the EU are make it different: the dominant position of one country (the USA) in the US North American economic region, weak interdependence of the economies of Canada and Mexico, the absence of special superstate institutions.

Table 4

Macroeconomic indicators of NAFTA (USMCA) member states, $\mathbf{2 0 1 8}^{17,18,19,20,21}$

\begin{tabular}{|l|c|c|c|c|}
\hline \multicolumn{1}{|c|}{ Indicator } & The USA & Canada & Mexico & NAFTA \\
\hline Population, thousand & 327,352 & 36,994 & 124,738 & 489084 \\
\hline Population, share in the world, \% & 4,25 & 0,5 & 1,55 & 6,3 \\
\hline Nominal GDP, trillion USD & 21,43 & 1,73 & 1,27 & 24,43 \\
\hline GDP, share in global, \% & 24,8 & 2,0 & 1,47 & 28,27 \\
\hline GDP per capita, USD & 64865 & 46487 & 9773 & 40375 \\
\hline Export, million USD & 1664085 & 449845 & 450572 & 2564502 \\
\hline Share in global export, \% & 8,6 & 2,3 & 2,3 & 13,2 \\
\hline Inflation rate, \% & 1,8 & 1,9 & 4,8 & 2,8 \\
\hline Public debt, \% of GDP & 104,3 & 89,9 & 53,6 & 82,6 \\
\hline
\end{tabular}

The goals pursued by the Member States, united in NAFTA, also differed. For the US, the North American Agreement, as part of US strategic policy, was intended to increase not only the economic but also the geopolitical power. For Mexico, NAFTA was needed to successfully implement economic reforms and modernize the economy through increased investment flow, as well as a decrease in the level of protection of the US market for Mexican goods. Canada's participation in the negotiations

17 Country comparison Mexico vs Canada. URL: https://countryeconomy.com/ countries/compare/mexico/canada

${ }^{18}$ GDP Ranked by Country 2019. URL: http://worldpopulationreview.com/countries/ countries-by-gdp/

${ }^{19}$ Projected GDP Ranking (2019-2024). URL.: http://statisticstimes.com/economy/ projected-world-gdp-ranking.php

${ }^{20}$ World's Top Export Countries.URL: http://www.worldstopexports.com/worlds-topexport-countries/

${ }_{21}$ Mapped: The World's Largest Exporters in 2018. URL: https://www. visualcapitalist.com/mapped-worlds-largest-exporters-in-2018/ 
provided Mexico with the opportunity to open a new export market and source of foreign investment ${ }^{22}$.

The dynamics of the aggregate macroeconomic indicator of GDP, calculated by purchasing power parity per capita, indicates that in all NAFTA countries there has been an increase in economic development and growth in the level of public welfare since the formation of the free trade area. During the 20-year period (1995-2015), thanks to liberalization, deepening the specialization of NAFTA countries and significant expansion of their trade and economic relations, Canada increased its GDP per capita by 2.69 times, the United States - by 1.86 times, and Mexico - by 1.7 times.

Figure 3 shows the GDP dynamics of the NAFTA countries since the implementation of the agreement - to this day.

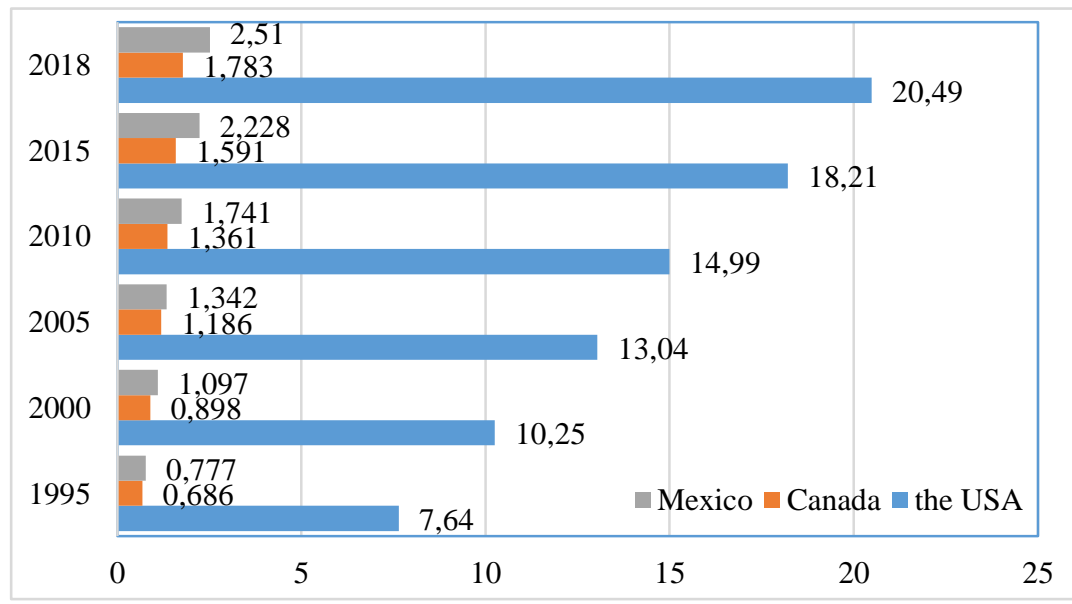

Fig. 3 GDP (purchasing power parity) of NAFTA countries, 1995-2018, USD trillion ${ }^{23}$

As can be seen from the figure, GDP has been growing in all economies since the agreement was introduced. The US economy grew 2.7 times, Canada 2.6 times, and Mexico 3.2 times. Thus, the economy of the least developed Mexico has been growing at the fastest rate, indicating a

22 Петухова О.В. Особливості інтеграційних процесів між державами, що мають різні моделі економічного розвитку (на прикладі інтеграційного об'єднання НАФТА. Ефективна економіка. 2014. № 9. URL: http://www.economy.nayka.com.ua/ ?op=1\&z=3360

23 GDP, PPP (current international \$) - Canada, Mexico, USA. URL: https:// data. worldbank.org/indicator/NY.GDP.MKTP.PP.CD?end=2018\&locations=CA-MXUS\&start=1995\&view $=$ chart 
narrowing of the gap between countries and a positive impact of the country's participation in integration.

Participation in NAFTA contributed to the annual growth of the US economy by $0.5 \%$, mainly due to the growth of agriculture, automotive production and services. Some sources say NAFTA exports have created 5 million jobs in the US. Most of these jobs positions were in 17 states, but there was a slight increase in all states. The US manufacturers have created more than 800,000 jobs between 1993 and 1997. Even imports of NAFTA partners have created jobs. Almost $40 \%$ of US imports from Mexico came from US companies. They developed products domestically and then transferred part of the process to Mexico ${ }^{24}$.

With regard to changes in GDP per capita, the experts' conclusion is that Mexico's participation in the integration union has slowed the growth of real incomes. At least, per capita GDP growth rates were much more modest than in other countries in the region. Mexico's GDP per capita growth rate was lower than in most Latin American countries in the 1994-2016 period - see Table 5.

During the period since NAFTA's existence, the per capita GDP gap has not narrowed significantly: in 1994, Mexico's figure was US \$ 8482, that is 3.4 times less than the US indicator and 2.75 less than for Canada. In 2018, GDP per capita in Mexico was \$19887, which is 3.15 times less than in the United States and 2.4 times less than in Canada - Figure 4.

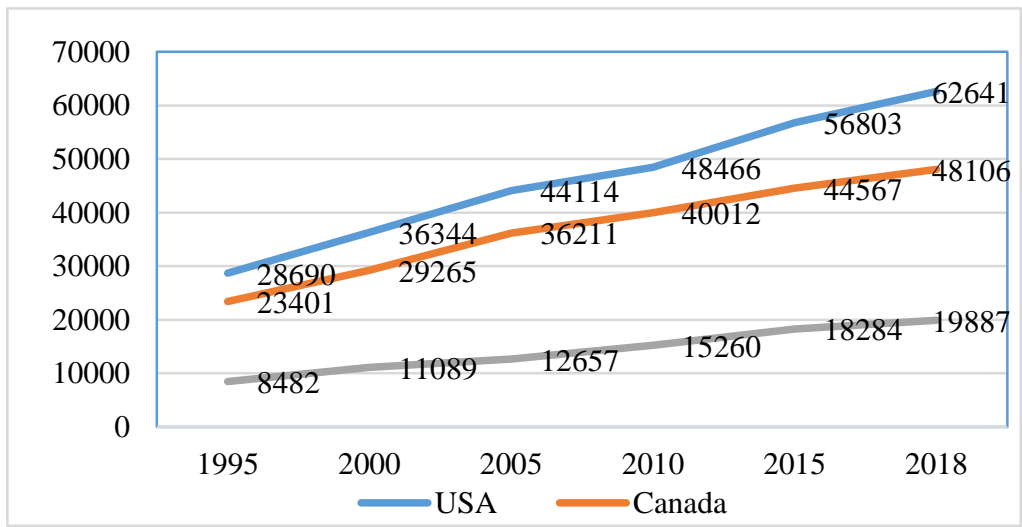

Figure 4. GDP per capita in the USA, Canada and Mexico, 1995-2018, US $\$$

${ }^{24}$ Amadeo K. The Hidden Benefits of NAFTA. URL: https://www.thebalance.com/ advantages-of-nafta-3306271

25 NAFTA's Winners and Losers. URL: https://www.investopedia.com/articles/ economics/08/north-american-free-trade-agreement.asp 


\section{Average annual GDP per capita growth in some countries of Latin America, 1994-2016 ${ }^{26}$}

\begin{tabular}{|l|c|}
\hline \multicolumn{1}{|c|}{ Country } & Average annual growth, \% \\
\hline Panama & 4.0 \\
\hline Peru & 3.2 \\
\hline Chile & 3.0 \\
\hline Guyana & 2.8 \\
\hline Surinam & 2.6 \\
\hline Costa Rica & 2.5 \\
\hline Nicaragua & 2.5 \\
\hline Bolivia & 2.3 \\
\hline Uruguay & 2.3 \\
\hline Colombia & 2.1 \\
\hline El Salvador & 1.9 \\
\hline Honduras & 1.9 \\
\hline Paraguay & 1.4 \\
\hline Ecuador & 1.4 \\
\hline Mexico & 1.2 \\
\hline Brazil & 1.1 \\
\hline Argentina & 1.1 \\
\hline Guatemala & 1.1 \\
\hline Belize & 1.0 \\
\hline Venezuela & -0.4 \\
\hline
\end{tabular}

Mexico's unemployment and poverty rates remain high, outbound migration flows are constantly increasing. The loss of nearly 1.3 million jobs in agriculture is considered the main negative aspect of NAFTA's impact on Mexico's economy. Most of the people who lost their jobs because of fierce competition with the US agricultural sector were mostly small-scale farmers engaged in corn and beans production. Most of these farmers were uneducated and unable to transfer their skills to new jobs. In despair, a large number of men emigrate to the United States searching for a better job ${ }^{27}$.

For Canada, the impact of integration with the United States and Mexico has been largely positive and has contributed to economic growth through deepening trade - in particular, through increased exports of oil to the United States. Prior to the implementation of the agreement, the US imported crude oil in the amount of $\$ 37.8$ billion in 1993, of which $18.4 \%$

${ }^{26}$ Weisbrot M., Merlin L., Lefebvre V., Sammut S. Did Nafta Help Mexico? An Update After 23 Years. URL: http://www.scielo.org.mx/scielo.php?script=sci_arttext\& pid=S1870-05782018000200159\&lng=es\&nrm=iso\&tlng=en

27 NAFTA and the FTAA: Impact on Mexico's Agriculture Sector. URL: https://www.iatp.org/sites/default/files/NAFTA_and_the_FTAA_Impact_on_Mexicos_Ag ricultu.pdf 
were from Saudi Arabia and only 13.2\% were from Canada. In 2015, Canada sold $\$ 49.8$ billion, or $41 \%$ of total crude exports to the US. In reality, US oil sales in Canada increased by 527\% during this period, and since 2006, Canada has been a major oil supplier to the United States. Canada's current share of crude oil imports to the United States is $48 \%{ }^{28}$.

At the same time, the stability of the price level for goods included in the consumer basket shows the positive impact of the NAFTA. The abolition of customs duties caused decrease in the cost of food for all NAFTA countries. In addition, one of the positive aspects of the impact on all countries is seen in the growth of foreign investment and mutual trade. At the same time, the dissatisfaction of the participating countries, first of all, the US, led to the revision of the terms of the agreement and the signing of a new integration agreement - NAFTA 2.0 (USMCA).

It can be stated that the integration within NAFTA is successful, because all countries in this integration integration, regardless of the model of economic development and existing gaps in socio-economic development, are solving the main goals and problems of their economies.

However it is important to emphasize that, nevertheless, Mexico is still lagging behind in economic development from the US and Canada.

\section{Differentiation of economic development within the ASEAN}

The deepening of economic ties between the countries together with maintaining geopolitical rivalry between them is a peculiarity of the development of the Asia-Pacific region. The share of East and Southeast Asian countries in world GDP exceeds that of the West and Japan combined. According to experts, this share can double the total GDP of EU countries by $2020^{29}$.

Participation in the economic organization of the Pacific region ASEAN - plays an important role in promoting the economic development of Southeast Asian countries. The Association of Southeast Asian Nations (ASEAN Association) was established on August 8, 1967 in Bangkok by five countries: Indonesia, Malaysia, Singapore, Thailand and the Philippines. Brunei joined the organization in 1984, Vietnam in 1995, Laos and Myanmar in 1997, and Cambodia in 1999. So currently there are 10 ASEAN member states. Papua New Guinea has the status of Special Observer ${ }^{30}$.

${ }^{28}$ Crude oil facts. URL: https://www.nrcan.gc.ca/science-data/data-analysis/energydata-analysis/energy-facts/crude-oil-facts/20064.

29 Мариніна С.В. Особливості розвитку інтеграційних угруповань в АзійськоТихоокеанському регіоні. Економічний часопис-XXI. 2013. № 1-2(2).URL: http:// nbuv.gov.ua/UJRN/ecchado_2013_1-2\%282\%29_4

30 Узун В.В. Тенденції розвитку процесів регіоналізації в країнах-членах АСЕАН. Вісник Запорізького національного університету. 2016. № 1 (29). С. 89-96. 
Although ASEAN is not a full-fledged integration entity like the EU or NAFTA, it is based on bilateral or multilateral preferential trade agreements. The reasons for the integration of countries are due, on the one hand, to economic factors, such as an increase in economic growth, rapid diversification of industrial exports and an increase in the inflow of foreign investment; on the other hand, political - thanks to regional cooperation and preferential arrangements, enhanced individual and collective bargaining positions, facilitating the conclusion of lucrative agreements with external partners. The formation of the ASEAN Free Trade Area now is the central point of ASEAN's activity. By the early 1990s, preferences covered 12,700 goods, duties for half of which had been reduced by $20-25 \%$. Through this agreement, a single preferential tariff scheme was approved, which reduced the mutual trade duty by $0-5 \%$ on all goods that satisfy the conditions of origin rule. In addition to the cancellation of duties, AFTA provides for reduction of quantitative restrictions, harmonization of national standards, mutual assignment of quality certificates, as well as the abolition of other non-tariff barriers. ASEAN's activities enhance cooperation in the areas of finance, telecommunications, tourism, communications, transportation and environmental protection ${ }^{31}$.

ASEAN countries are experiencing relatively high economic growth rates $-5.1 \%$ in 2018 , driven by increased domestic demand and increased investment. By some indicators, the integration rate is much higher than in developed countries. Table 6 shows the growth rates of some ASEAN indicators compared to the world, as well as the US and China.

Table 6

GDP, foreign trade and FDI growth rates of ASEAN, USA and China ${ }^{32}$

\begin{tabular}{|c|c|c|c|c|c|c|c|c|c|}
\hline \multirow[b]{2}{*}{ Indicator } & \multicolumn{3}{|c|}{ ASEAN } & \multicolumn{3}{|c|}{ China } & \multicolumn{3}{|c|}{ USA } \\
\hline & \begin{tabular}{|c|}
$2010-$ \\
2016
\end{tabular} & 2017 & 2018 & $\begin{array}{c}2010- \\
2016\end{array}$ & 2017 & 2018 & $\begin{array}{c}2010- \\
2016\end{array}$ & 2017 & 2018 \\
\hline $\begin{array}{l}\text { Real GDP growth rate, } \\
\%\end{array}$ & 5,5 & 5,3 & 5,1 & 8,1 & 6,8 & 6,6 & 2,2 & 2,2 & 2,9 \\
\hline $\begin{array}{l}\text { Foreign trade in goods } \\
\text { growth rate, } \%\end{array}$ & 5,5 & 15,0 & 8,1 & 7,6 & 11,4 & 12,6 & 4,8 & 6,9 & 8,2 \\
\hline $\begin{array}{l}\text { Foreign trade in } \\
\text { services growth rate, } \%\end{array}$ & 5,0 & 5,6 & 6,9 & 9,0 & 6,1 & 6,9 & 11,6 & 5,1 & 13,8 \\
\hline FDI growth rate, $\%$ & 15,5 & 23,5 & 5,3 & 5,0 & 0,3 & 3,7 & 18.5 & $-41,2$ & $-9,2$ \\
\hline
\end{tabular}

31 Черняга Л.П. Особливості економічного розвитку країн Південно-Східної Азіï. URL: http://intrel.lnu.edu.ua/wp-content/uploads/2015/10/Черняга-Л.П.-Особли вості-економічного-розвитку-країн-Південно-Східної-Азії.pdf

32 ASEAN economic integration brief. URL: https://asean.org/resources_cat/aseanpublications-3/ 
As it can see from the table, ASEAN is ahead of the growth rate of all the analyzed US indicators, and in terms of growth of FDI in general shows a striking dynamics $-15.5 \%$ growth for 2010-2016 and + 23\% in 2017 .

Among all ASEAN countries, Myanmar had the highest growth rates during 2010-2016, and Brunei had the lowest growth rates (Figure 5).

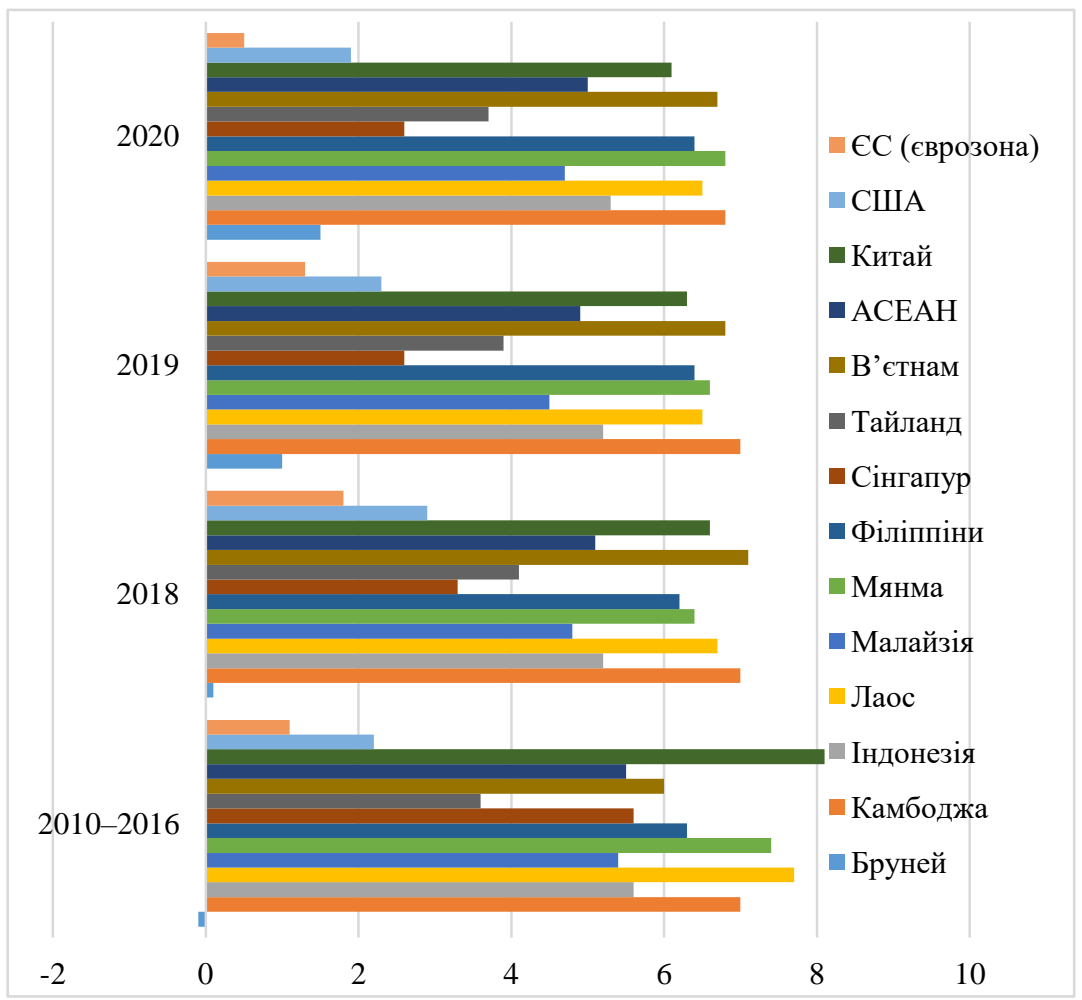

Figure 5. GDP growth rates of ASEAN countries, the EU, the USA, 2010-2020(forecast), $\%^{33}$

In 2017-2018, Vietnam and Cambodia had the leading pace. All ASEAN countries are projected to maintain positive real GDP growth in 2020, which will exceed the pace of the EU, Japan, the US, but will be more moderate than the growth of the leading new industrial countries in Asia like China and India.

\footnotetext{
33 ASEAN economic integration brief. URL: https://asean.org/resources_cat/aseanpublications-3/
} 
However, the considerable heterogeneity in the existing levels of development of the member countries is peculiar for ASEAN and is unlikely to be eliminated in the near future. The union has rich members like Brunei, whose economy is based on oil exports, dynamic and technological Singapore, industrial Malaysia and the Philippines. At the same time, it unites the poorest countries in the world - Laos, Cambodia and Myanmar. Most of the union's GDP is created by Indonesia (35\%).

Table 7 summarizes the key macroeconomic indicators of the ASEAN countries for 2018. The table shows that Singapore was the richest country in 2018 in terms of GDP per capita $(\$ 64,273)$, Myanmar was the poorest $(\$ 1,328)$. Thus, the gap between the largest and the smallest indicator was 48 times.

Table 7

ASEAN core macroeconomic indicators in $2018^{34,35,36,37}$

\begin{tabular}{|l|c|c|c|c|c|}
\hline Country & $\begin{array}{c}\text { GDP, at } \\
\text { current } \\
\text { prices, } \$ \\
\text { billion }\end{array}$ & $\begin{array}{c}\text { GDP per } \\
\text { capita, } \$\end{array}$ & $\begin{array}{c}\text { Inflation } \\
\text { rate, } \%\end{array}$ & $\begin{array}{c}\text { Unemploym } \\
\text { ent rate, \% }\end{array}$ & $\begin{array}{c}\text { Public debt, } \\
\text { \% to GDP }\end{array}$ \\
\hline Brunei & 13,6 & 31895 & 0,2 & 9,22 & 2,4 \\
\hline Cambodia & 24,5 & 1535 & - & 1,05 & 29,4 \\
\hline Indonesia & 1041,6 & 3928 & 3,2 & 5,3 & 29,8 \\
\hline Laos & 18,1 & 2627 & 2,0 & 0,61 & 53,3 \\
\hline Myanmar & 71,5 & 1328 & 6,9 & 2,1 & 49,4 \\
\hline Malaysia & 354,2 & 10907 & 0,9 & 3,4 & 51,8 \\
\hline Philippines & 342,6 & 3213 & 5,3 & 6,6 & 41,9 \\
\hline Singapore & 361,0 & 64273 & 0,4 & 3,1 & 112 \\
\hline Thailand & 505,1 & 7443 & 1,1 & 1,2 & 41,8 \\
\hline Vietnam & 240,7 & 2542 & 7,1 & 2,0 & 57,5 \\
\hline ASEAN & $\mathbf{2 9 7 2 , 9}$ & $\mathbf{4 5 7 7}$ & - & & \\
\hline
\end{tabular}

The level of public debt relative to GDP was the lowest in Brunei (2.4\%), the highest in Singapore (112\%).

Finally, the Competitiveness Index and Human Development Index show the dynamics of economic development and the quality of life of the population in the most generalized way. For ASEAN countries, the change in the the Competitiveness Index between 2014 and 2019 is shown in Table 8.

\footnotetext{
${ }^{34}$ ASEAN Key Figures 2018. URL: https://www.aseanstats.org/wp-content/uploads/ 2018/12/ASEAN-Key-Figures-2018.pdf

${ }^{35}$ Brunei Darussalam: Unemployment rate from 1998 to 2018. URL: https://www. statista.com/ statistics/526790/unemployment-rate-in-brunei-darussalam/

${ }^{36}$ Laos: Unemployment rate from 1998 to 2018. URL: https://www.statista.com/ statistics/808758/unemployment-rate-in-laos/

${ }^{37}$ Country List Government Debt to GDP - Asia. URL: https://tradingeconomics.com/ country-list/government-debt-to-gdp?continent=asia
} 
Global Competitiveness iIndex of the ASEAN countries, 2014 and $2019^{38,39}$

\begin{tabular}{|l|c|c|c|c|}
\hline \multicolumn{1}{|c|}{ Country } & GCI in 2019* & Rate in 2019 & GCI in 2014** & Rate in 2014 \\
\hline Brunei & 62,8 & 56 & 4,5 & 46 \\
\hline Cambodia & 52,1 & 106 & 3,89 & 95 \\
\hline Indonesia & 64,6 & 50 & 4,57 & 43 \\
\hline Laos & 50,1 & 113 & 3,91 & 93 \\
\hline Myanmar & - & - & 3,24 & 134 \\
\hline Malaysia & 74,6 & 27 & 5,16 & 20 \\
\hline Philippines & 61,9 & 64 & 4,40 & 54 \\
\hline Singapore & 84,8 & 1 & 5,65 & 2 \\
\hline Thailand & 68,1 & 40 & 4,66 & 31 \\
\hline Vietnam & 61,5 & 67 & 4,23 & 68 \\
\hline
\end{tabular}

$*$ Scale from 0 to $100 ; * *$ Scale from 0 to 7

As Table 9 shows, one of the ASEAN countries, Singapore, ranks first in the global competitiveness rankings of 2019. Malaysia is in the top 30, however having moved up down from $20^{\text {th }}$ to $27^{\text {th }}$ place in 5 years. The gap between the highest and lowest indicators of the group is 112 positions in 2019 (132 positions in 2014), i.e. the gap has narrowed slightly. However, the table still shows that the ASEAN countries have an extremely large gap in terms of competitiveness of national economies.

In terms of human development, the gap between the highest (Singapore, 9th) and the lowest rate (Myanmar, 145th) was 136 positions in 2018, comparing with 141 in 2013, see table 9.

Table 9

Human Development Index of ASEAN countries, 2018 and $2013^{40,41}$

\begin{tabular}{|l|c|c|c|c|}
\hline \multicolumn{1}{|c|}{ Country } & HDI in 2018 & Rank in 2018 & HDI in 2013 & Rank in 2013 \\
\hline Brunei & 0,845 & 43 & 0,859 & 30 \\
\hline Cambodia & 0,581 & 146 & 0,584 & 136 \\
\hline Indonesia & 0,707 & 111 & 0,684 & 108 \\
\hline Laos & 0,604 & 140 & 0,569 & 139 \\
\hline Myanmar & 0,584 & 145 & 0,524 & 150 \\
\hline Malaysia & 0,804 & 61 & 0,773 & 62 \\
\hline Philippines & 0,712 & 106 & 0,660 & 117 \\
\hline Singapore & 0,935 & 9 & 0,901 & 9 \\
\hline Thailand & 0,765 & 77 & 0,722 & 89 \\
\hline Vietnam & 0,693 & 118 & 0,636 & 121 \\
\hline
\end{tabular}

${ }^{38}$ The Global competitiveness report 2019. URL: http://www3.weforum.org/docs/ WEF_TheGlobalCompetitivenessReport2019.pdf

${ }^{39}$ The Global competitiveness report 2014. URL: http://www3.weforum.org/docs/ WEF_GlobalCompetitivenessReport_2014-15.pdf

${ }^{40}$ Human Development Report 2014. URL: http://hdr.undp.org/sites/default/files/ hdr14-report-en-1.pdf

${ }^{41}$ Human Development Index 2019. URL: http://hdr.undp.org/en/composite/HDI 
Singapore, Malaysia and Brunei are he countries with the highest HDI Among ASEAN countries with high human development. However, Brunei has moved from 30th to $43^{\text {rd }}$ position by 2018. Myanmar, Philippines and Thailand have improved their human development over the past 5 years.

Thus, ASEAN countries are developing dynamically, as evidenced by the rapid growth of GDP, but human development indicators have not improved significantly over the last 5 years, and the imbalances in socio-economic development have been declining rather slowly.

\section{CONCLUSIONS}

In the modern sense, international economic integration is a high level of international economic relations, during which the process of economic and political unification of countries takes place on the basis of international division of labor and implementation of a concerted international trade and economic policy. International economic integration usually begins with the creation of preferential conditions in mutual trade and the creation of a zone of preferential trade and can progress to the highest stage of development - an economic and political union, under which higher supranational institutions are delegated powers not only in the sphere of regulation of international trade, but also in political and security spheres.

It is considered that more developed countries with close levels of economic development and high indicators of productive forces are integrated more effectively. However, according to international practice, there are examples when countries which are characterized by significant differences in levels and rates of economic development effectively interact within the integration entities.

Integration processes can have positive effects on economies if they pursue their respective interests, but integrating countries tend to have unequal levels of socio-economic development and do not all develop according to the same patterns of economic development. Unequal development between the integrating countries may be caused by different models of economic development of the countries, different starting conditions and other external factors.

A study of EU development indicators found that while maintaining the high integrated indicators of the most developed EU countries, the so-called "old" members, their development rates are far behind the "new" members that joined after 2004, resulting in a gap that is gradually narrowing. The elimination of uneven development within the EU is the result of a highly effective EU regional policy. 
The North American Free Trade Area is the most ambiguous integrative integration of the world, both in terms of the interests pursued by the parties involved, and in terms of influencing the economic development of the parties. Mexico's development rate is far behind that of most Latin American countries, and competition from the US agricultural sector has led to significant unemployment in the country and increased emigration. Canada has been largely positive about participating in the growing foreign trade deal with the US and Mexico. The United States remains dissatisfied with the terms of participation in the merger and has initiated a revision of its terms (NAFTA 2.0).

The ASEAN countries are characterized by both the highest rates of development and the largest gap between indicators of the countries. The union is One of the countries leading the global competitiveness index in recent years - Singapore, one of the richest countries in the world - the Kingdom of Brunei, and the poorest countries in Laos and Myanmar are among the ASEAN members.

\section{SUMMARY}

The study covers the analysis of differences in economic development of three leading integrations of the world, representing Europe (the European Union), the North America (the NAFTA) and Asia (the ASEAN). It is underlined that integration not always leads to an equal effect on the member states, however some unions like the EU undertake special meaures aimed at reduction of disproportions in economic development. The dynamics of changes is analysed through macroeconomic indicators (GDP per capita, inflation rate, unemployment rate, public debt) and progress of countries in Human Development Index and Global Competitiveness Index.

\section{REFERENCES}

1. Носа А.М. Економічна нерівність у країнах Свропейського Союзу та iї вплив на місце ЄС у світовому економічному середовищі. Науковий вісник УжНУ. Серія «Міжнародні економічні відносини та світове господарство». 2017. Вип. 13. Ч. 2. С. 51-55. URL: http://www. visnyk-econom.uzhnu.uz.ua/archive/13_2_2017ua/13.pdf.

2. The World's $\$ 86$ Trillion Economy Visualized in One Chart. URL: https://howmuch.net/articles/the-world-economy-2018.

3. US vs EU - A GDP Comparison. URL: https://mgmresearch.com/usvs-eu-a-gdp-comparison/. 
4. National debt in EU countries in the 1st quarter 2019 in relation to gross domestic product. URL: https://www.statista.com/statistics/269684/ national-debt-in-eu-countries-in-relation-to-gross-domestic-product-gdp/.

5. National debt in the member states of the European Union in the 1st quarter 2019 (in billion euros). URL: https://www.statista.com/statistics/ 274179/national-debt-in-eu-countries/

6. Inflation rate in EU countries in June 2019 (compared to the same month of the previous year). URL: https://www.statista.com/statistics/ 225698/monthly-inflation-rate-in-eu-countries/

7. Gross domestic product (GDP) at current market prices of selected European countries in 2018 (in billion euros). URL: https://www.statista.com/ statistics/685925/gdp-of-european-countries/

8. These EU countries have the most government debt. URL: https:// www.weforum.org/agenda/2019/05/european-countries-with-mostgovernment-debt-chart/

9. GDP per capita (current US\$) - Poland, Greece, Portugal, Germany, European Union. URL: https://data.worldbank.org/indicator/NY.GDP. PCAP.CD?locations=PL-GR-PT-DE-EU\&name_desc $=$ true.

10. Poverty Rate (OECD Data). URL: https://data.oecd.org/inequality/ poverty-rate.htm.

11. Euro area unemployment at $7.5 \%$ EU28 at 6.3\%. URL: https://ec.europa.eu/eurostat/documents/2995521/10075437/3-29112019BP-EN.PDF/749d647b-6961-5d3d-a8c6-8eaca44a539d

12. Human Development Report 2014. URL: http://hdr.undp.org/sites/ default/files/hdr14-report-en-1.pdf.

13. Human development index 2019. URL: http://hdr.undp.org/en/ composite/HDI.

14. The Global competitiveness report 2019. URL: http://www3. weforum.org/docs/WEF_TheGlobalCompetitivenessReport2019.pdf

15. The Global competitiveness report 2014. URL: http://www3. weforum.org/docs/WEF_GlobalCompetitivenessReport_2014-15.pdf.

16. Кузнецкая О.Д., Шапкина И.Н. История экономики. Москва : ИНФРА-М, 2002. 384 с.

17. Country comparison Mexico vs Canada. URL: https://country economy.com/countries/compare/mexico/canada

18. GDP Ranked by Country 2019. URL: http://worldpopulationre view.com/countries/countries-by-gdp/

19. Projected GDP Ranking (2019-2024). URL: http://statisticstimes.com/ economy/projected-world-gdp-ranking.php

20. World's Top Export Countries. URL: http://www.worldstop exports.com/worlds-top-export-countries/ 
21. Mapped: The World's Largest Exporters in 2018. URL: https://www.visualcapitalist.com/mapped-worlds-largest-exporters-in-2018/

22. Петухова О.В. Особливості інтеграційних процесів між державами, що мають різні моделі економічного розвитку (на прикладі інтеграційного об'єднання НАФТА. Ефективна економіка. 2014. № 9. URL: http://www.economy.nayka.com.ua/?op=1\&z=3360

23. GDP, PPP (current international \$) - Canada, Mexico, USA. URL: https://data.worldbank.org/indicator/NY.GDP.MKTP.PP.CD?end=2018\&loc ations $=$ CA-MX-US\&start $=1995 \&$ view $=$ chart.

24. Amadeo K. The Hidden Benefits of NAFTA. URL: https://www. thebalance.com/advantages-of-nafta-3306271.

25. Weisbrot M., Merlin L., Lefebvre V., Sammut S. Did Nafta Help Mexico? An Update After 23 Years. URL: http://www.scielo.org.mx/ scielo.php?script=sci_arttext\&pid=S1870-05782018000200159\&lng=es\&n $\mathrm{rm}=\mathrm{iso} \&$ tlng $=\mathrm{en}$

26. NAFTA's Winners and Losers. URL: https://www.investo pedia.com/articles/ economics/08/north-american-free-trade-agreement.asp

27. NAFTA and the FTAA: Impact on Mexico's Agriculture Sector. URL: https://www.iatp.org/sites/default/files/NAFTA_and_the_FTAA_ Impact_on_Mexicos_Agricultu.pdf.

28. Crude oil facts. URL: https://www.nrcan.gc.ca/science-data/dataanalysis/energy-data-analysis/energy-facts/crude-oil-facts/20064.

29. Мариніна С.В. Особливості розвитку інтеграційних угруповань в Азійсько-Тихоокеанському регіоні. Економічний часопис-XXI. 2013. № 1-2(2). URL: http://nbuv.gov.ua/UJRN/ecchado_2013_1-2\%282\%29_4

30. Узун В.В. Тенденції розвитку процесів регіоналізації в країнахчленах АСЕАН. Вісник Запорізького національного університету. 2016. № 1 (29). С. 89-96.

31. Черняга Л.П. Особливості економічного розвитку країн Південно-Східної Азії. URL: http://intrel.lnu.edu.ua/wp-content/uploads/ 2015/10/Черняга-Л.П.-Особливості-економічного-розвитку-країнПівденно-Східної-Азії.pdf

32. ASEAN economic integration brief. URL: https://asean.org/ resources_cat/asean-publications-3/

33. ASEAN Key Figures 2018. URL: https://www.aseanstats.org/wpcontent/uploads/2018/12/ASEAN-Key-Figures-2018.pdf

34. Brunei Darussalam: Unemployment rate from 1998 to 2018. URL: https://www.statista.com/statistics/526790/unemployment-rate-in-bruneidarussalam/

35. Laos: Unemployment rate from 1998 to 2018. URL: https://www.statista.com/statistics/808758/unemployment-rate-in-laos/ 
36. Country List Government Debt to GDP - Asia. URL: https://tradingeconomics.com/country-list/government-debt-to-gdp?conti nent=asia.

Information about the authors:

Palinchak M. M.,

Doctor of Political Science, Professor, Dean of the Faculty of International Economic Relations

Uzhhorod National University 14, Universytetska str., Uzhhorod, 88000, Ukraine

Brenzovych K. S., $\mathrm{PhD}$ in Economics, Associate Professor at the Department of International Economic Relations Uzhhorod National University 14, Universytetska str., Uzhhorod, 88000, Ukraine

Mashkara-Choknadiy V. V., Lecturer at the Department of International Economic Relations

Uzhhorod National University 14, Universytetska str., Uzhhorod, 88000, Ukraine 